CIHM Microfiche Series (Monographs)
ICMH

Collection de microfiches (monographies)

Canadian Institute for Historical Microreproductions / Institut canadien de microreproductions historiques
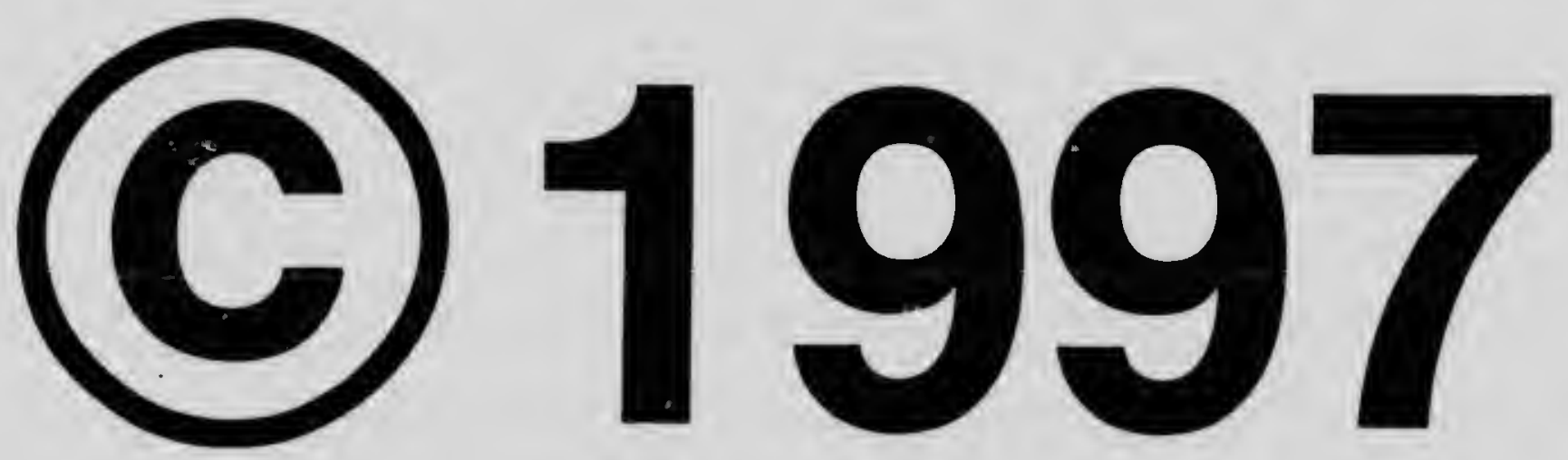


\section{Technical and Bibliographic Notes / Notes techniques et bibliographiques}

The Institute has attempted to obtain the best original copy avallable for filming. Features of this copy which may be bibliographlcally unlque, which may alter any of the Images in the reproduction, or which may slgnificantly change the usual method of filming are checked below.

\section{Coloured covers /}

Couverture de couleur

\section{Covers damaged /}

Couverture endommagée

Covers restored and/or laminated /

Couverture restaurée et/ou pelliculée

Cover title missing / Le titre de couverture manque

Coloured maps / Cartes géographiques en couleur

Coloured ink (i.e. other than blue or black) /

Encre de couleur (i.e. autre que bleue ou noire)

Coloured plates and/or illustrations /

Planches et/ou illustrations en couleur

Bound with other material /

Relié avec d'autres documents

Only edition available /

Seule édition disponible

Tight binding may cause shadows or distortion along interior margin / La reliure serrée peut causer de l'ombre ou de la distorsion le long de la marge intérieure.

Blank leaves added during restorations may appear within the text. Whenever possible, these have been omitted from filming / II se peut que certaines pages blanches ajoutées lors d'une restauration apparaissent dans le texte, mais, lorsque cela était possible, ces pages n'ont pas été filmées.

Additional comments /

Commentaires supplémentaires:
L'Institut a microfilmé le meilleur exemplalre qu'il lul a été possible de se procurer. Les détalls de cet exem. plalre qui sont peut-être uniques du point de vue bibliographique, qui peuvent modifier une image reproduite, ou qui peuvent exiger une modification dans la méthnde normale de filmage sont indiqués ci-dessous.

\section{Coloured pages / Pages de couleur}

Pages damaged / Pages endommagées

Pages restored and/or laminated /

Pages restaurées et/ou pelliculées

Pages discoloured, stained or foxed /

Pages décolorées, tachetées ou piquées

\section{Péges detached / Pages détachées}

Showthrough / Transparence

Quality of print varies /

Qualité inégale de l'impression

Includes supplementary material /

Comprend du matériel supplémentaire

Pages wholly or partially obscured by errata slips, tissues, etc., have been refilmed to ensure the best possible image / Les pages totalement ou partiellement obscurcies par un feuillet d'errata, une pelure, etc., ont été filmées à nouveau de façon à obtenir la meilleure image possible.

Opposing pages with varying colouration or discolourations are filmed twice to ensure the best possible image / Les pages s'opposant ayant des colorations variables ou des décolorations sont filmées deux fois afin d'obtenir la meilleure image possible.

This item is filmed at the reduction ratio checked below /

Ce document est filmé au taux de réduction indiqué ci-dessous.

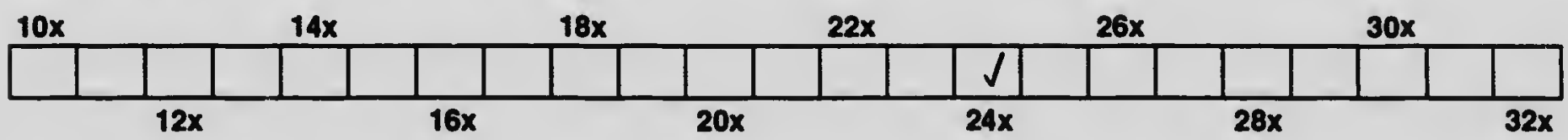


The copy flimed here has been reproduced thanks to the genorosity of:

National Library of Canada

The images appearing here are the best quaity posalble conaldering the conditlon and loglbility of the orloinal copy and In keeping with the fiiming contract speclfications.

Originol copies in printed peper covere are flimed beginning with the front cover and ending on the last page with a printed or lilustrated impression, or the back cover when appropriate. Aii other original copies are fiimed beginning on the flrat page with a printed of lllustrated impression, and ending on the lost page with a printed or lllustrated impresaion.

The last recorded frame on each microflehe shall contain the symbol - Imeaning "CON. TINUED"), of the symbol $\nabla$ (meaning "END"). whichover applies.

Maps, piates. charts. etc., may be filmed at different reduction retios. Those too large to be entirely included in one exposure are filmed beginning in the uppor latt hand corner. left to right and top to bottom, as many frames as required. The following diagrams illustrate the mothod:
L'exempiaire fllmb fut reproduit grdce $d$ is gónbrosits da:

Bibliothèque nationale du Canada

Lee images sulvantes ont dt reproduitas svec le plus grend soin, compte tenu de la condition at de la nortots de l'exemplaire filmb. ot an conformitt avec les conditions du contrat de fiimage.

Les oxemplalres origineux dont la couverture en popier eat Imprimbe sont fllmbse en commençant par io premier plat et en torminent soit per le dernidre page qul comporte une emprainte d'Impresalon ou d'illustration. soit per le second plat. selon lo cas. Tous los sutres exemplaires orloineux sont fllmbs en commençont por le premlere page qul comporte une empreinte d'impression ou d'lllustration ot en terminent par la dernidre page qui comporte une talla emprointe.

Un des eymboles suivants epperaitra sur la dernidre image de cheque microfiche. selon le cas: lo symbole $\longrightarrow$ signifie "A SUIVRE". Io ormbole $\nabla$ signifle "FIN".

Lee cartes, planches, tableeux. otc.. peuvent ótre filmbs doe taux de reduction diffirents. Lorsque lo document est trop grand poup atre roproduit on un soul clicho. il eat filmo a sit Jrtir de l'angle supdriour gauche. de gauche aroite. et de haut en bas. on prenant le nombre d'imeges ndcesseire. Les diagrammes suivents illustrent la mothode.
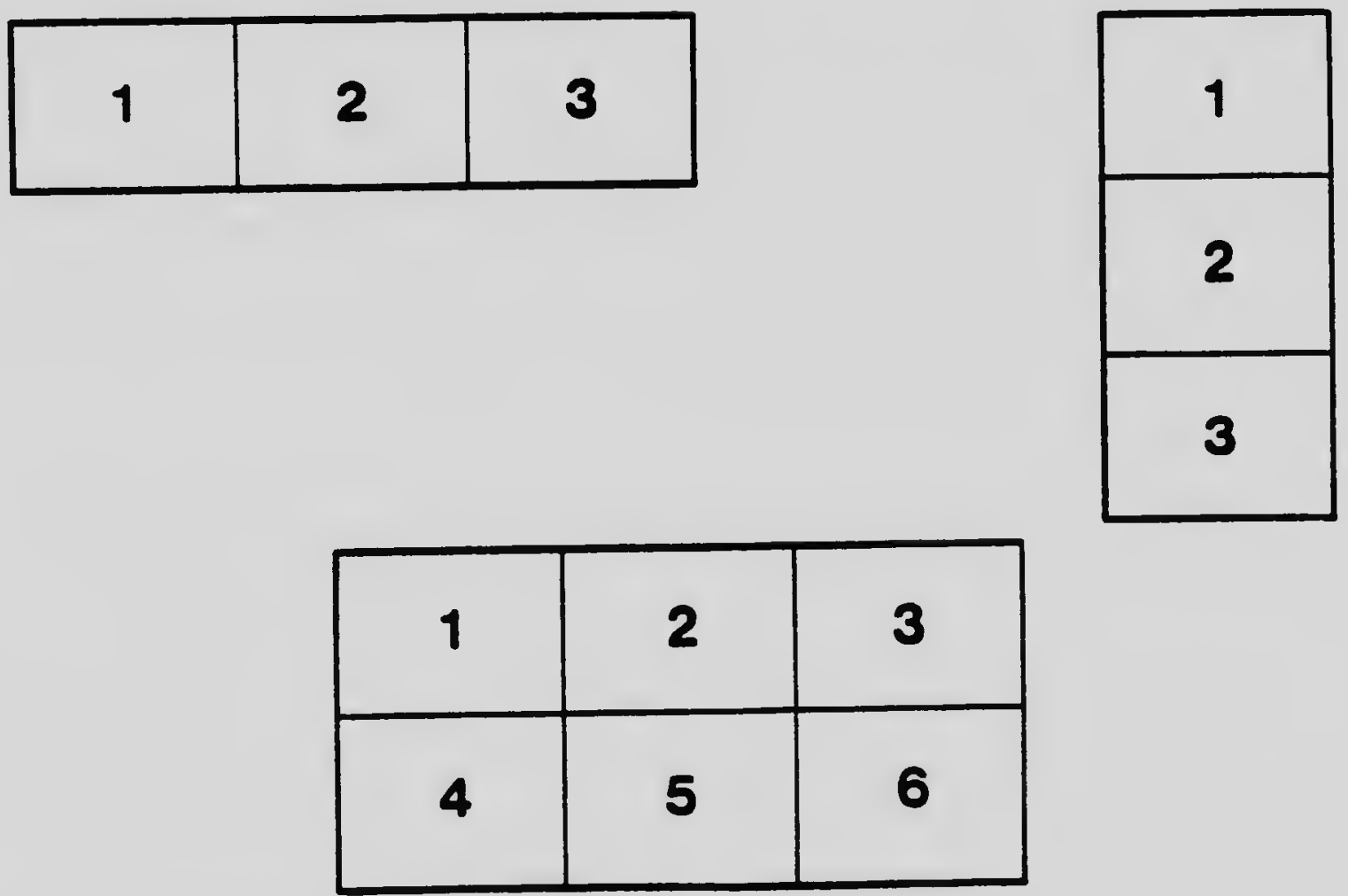
MICROCON RESOLUTION TEST CHART

(ANSI and ISO TEST CHART No. 2)

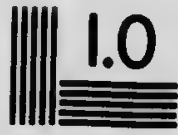

14502.8

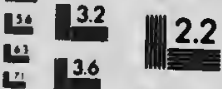

$\|$ III 1.1

40

는
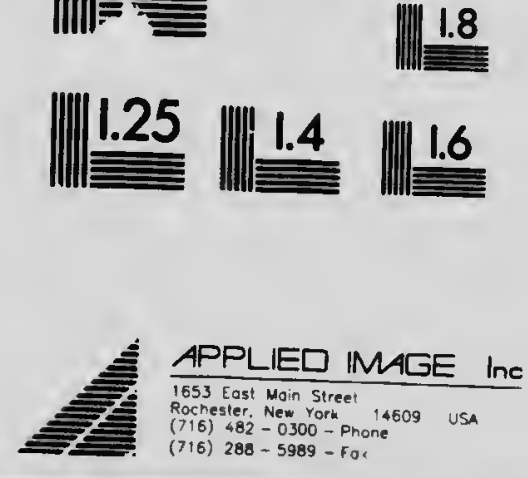


\section{OYster FARMING}

IN

\section{Prince Edward Istaand}

\section{BY \\ M. J. PATTON}

ASSISTANT SECRETARY.

COMMISSION OF CONSERVATION

eprinted from the Fourth Annual Report

of the Commisston of Conservation

OTTAWA : COMHISSION OF CONSERVATION : 1913 


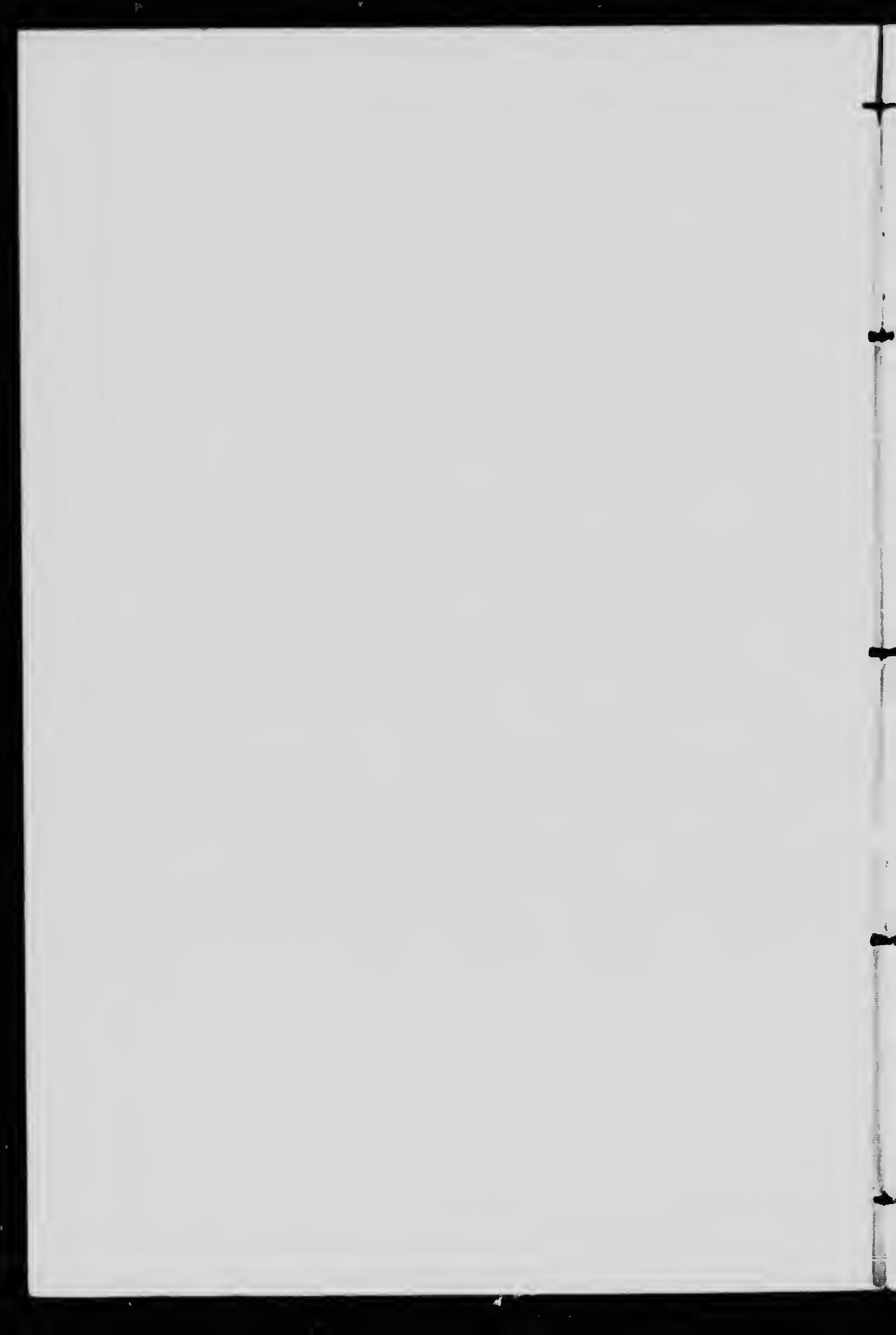




\title{
Oyster Farming in Prince Edward Island
}

\author{
טצ \\ II. J. Patton \\ Assistant Secrelary of the Commission of Conscruation
}

$\mathrm{D}^{2}$ CIRING the past yea the Dominion Prorlinment waved its claim to granting leases o the cyster areas of Cunala, ind, consequently, the clisposal of these arens now restw entirely with the provinces. The net grunting these eoneessions wns passed at the last gession of the Dominion Parliament. It empowers the govemior in couneil to " Huthorize the governnent of auy provinee to grant lenses of such areas of the sea enast, hays, inlets, hurbours, creeks, rivers and estunries of such provinces as the government of sueh province eonsiclers suitahle for the cultivation and preduetion of oysters." Thus a wny was opened up wherehy the disposition of loth the harren and the prolueing oyster areas coull he placel under provineial jurisdiction. The provinees were not slow to take ndruntuge of this and Norn Scotin, Prinee Filwarl Island, New Brunswick and British Columbia-all the oysterprolueing provinees-have entered into arrements with the Dominion corsument, giving then tlie undisputed right to lease tlie oyster areas within their hounclaries. While the Dominion thus relinquished its claim to the clisposal of these hottoms. it still possesses the iull legislative jurisliction, as confirmed by the derision of the Jurlieial Committee of the Imperial Privy Couneil in 1598, and makes and enforees all laws and regulntions under which the nyster fishery is earried on.

Survey of

Richmond Buy
Is soon as the agreement witls the Dominion was cuted, the government of Prince Fdward Island took steps to make arailable to its inhabitants the large nreas Gi putentinl nyster areas that it possessml. Preparatory to granting l.oses. Mr. II. II. Shaw. Provineial Enuineer, was detailed to make a survey of all the tidal rivers and constal waters. During 1912 he eomphotid a survey of Riehmond bay, which, before its depletinn, produeed large quantities of the faunous Mnlpeque oysters. It was found to contnin approximately 14,700 acres, most of which is available for oyster multure. The plan of survey shows the hay divided into 20-nere plots, early of which is div led into four plots of 5 sores each. The depth of the water at low tide and the eharacter of the bottom are also indieated.

[3] 
In 1913, alditiounl parties will be detailed to the work, and the nurvey of the remaining arean completed as rapidly an posiljle. An l'rivec Edwnrd Island has a coast line sone 800 miles in length, this is a work of no smull mugnitude.

When the survey wis nearing eompletion, the Provineial Leadis: Retculations government formulated regulations for the inening of lenes and in the untumn of 1912 applicationa for lenses of areas in Rielumond bay were reeeived. On Oetober 17 th, applieations were called for from adult persons who had been residents of the Island for at least one year. Kiparian owner were given the first ofportunity to seeure lease of 5 -nere ploth contiguous to their property, and, after these applientions had been filled, the applientions of other residents were considered. In the ease of two persons, not riparian owners, apply. ing for the same plot and failing to arrive at a satisfactory settlement, the lense to tho disputed area was put up at suction and sold to the highest bidder. The time for receiving applications expired on November 20 th, hut a second opportunity to obtain areas, extending from November 30 th to December 16th, was given to residents. This time they were not restricted to 5-acre plots and those who had already been granted leases were allowed to obtain additional areas. After December 16th, applieations for leases from non-residents of the Island were eonsidered.

The lense extends over a term of twenty years and, at its expiration, is renewable at the oprion of the lessee for a further perind of twenty years. The rent charged is $\$ 1$ an acre for each of the first five years, $\$ 3$ an nere for each of the seeond five years and $\$ 5$ an acre for each of the remnining ten years. If the lense is renewed, the rent for each of the seeond twenty years is at the rate of i, per aere per yenr, and, in addition, the lessee must agree to pay any royalty on the oysters produced, which the Province may levy. Arens leased eannot be sub-let or otherwise disposel of exeept on the written consent of the Attcrney General of the Pmvinee, and the lense is subject to eancellation unless the beds are properly eultivited and maintained.

Available Oyster Area

Until the survey is finished tr- $-e n$ available for orster farming will not be deficitely ..nown. There are. however, eertain portions of the foreshore of the Provinee that have prolueed oysters in varying quantities ever since the Island wins settled, nnd it $i$ fair assumption that harren areas in these distriets can be eultivated suceessfully. The greater portion of the oysters 


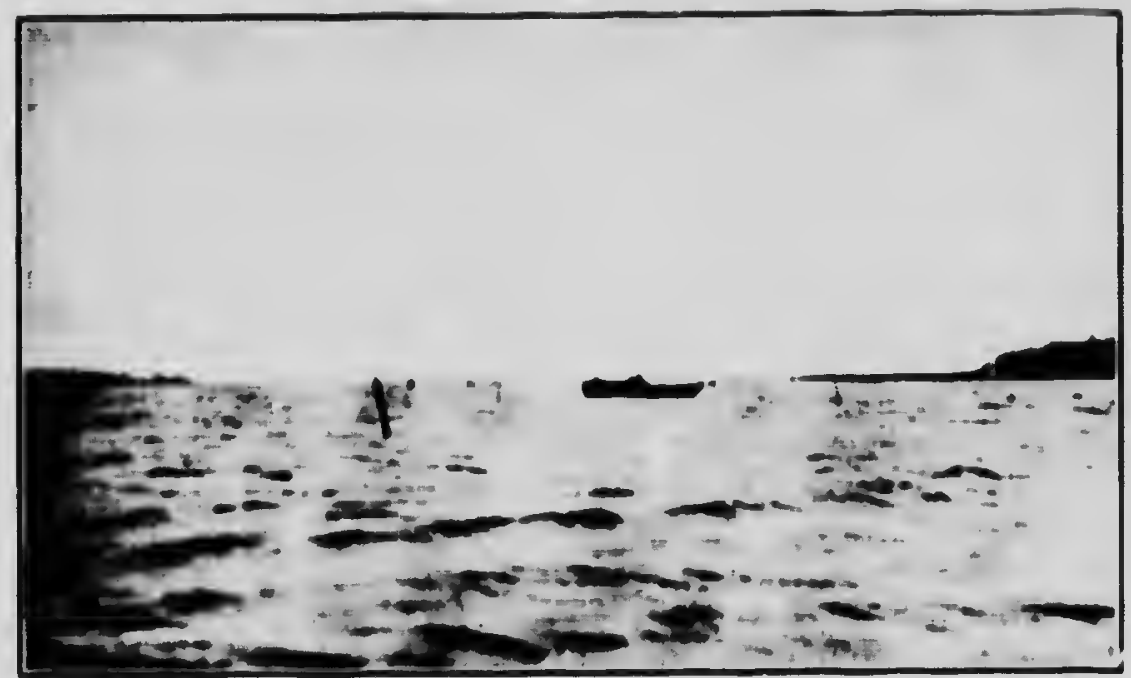

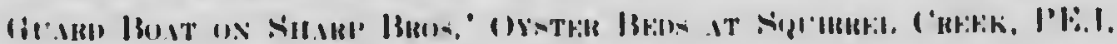

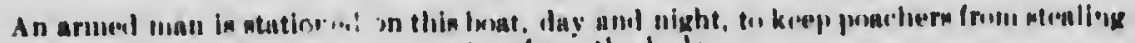
nymerore ironii the linetle.

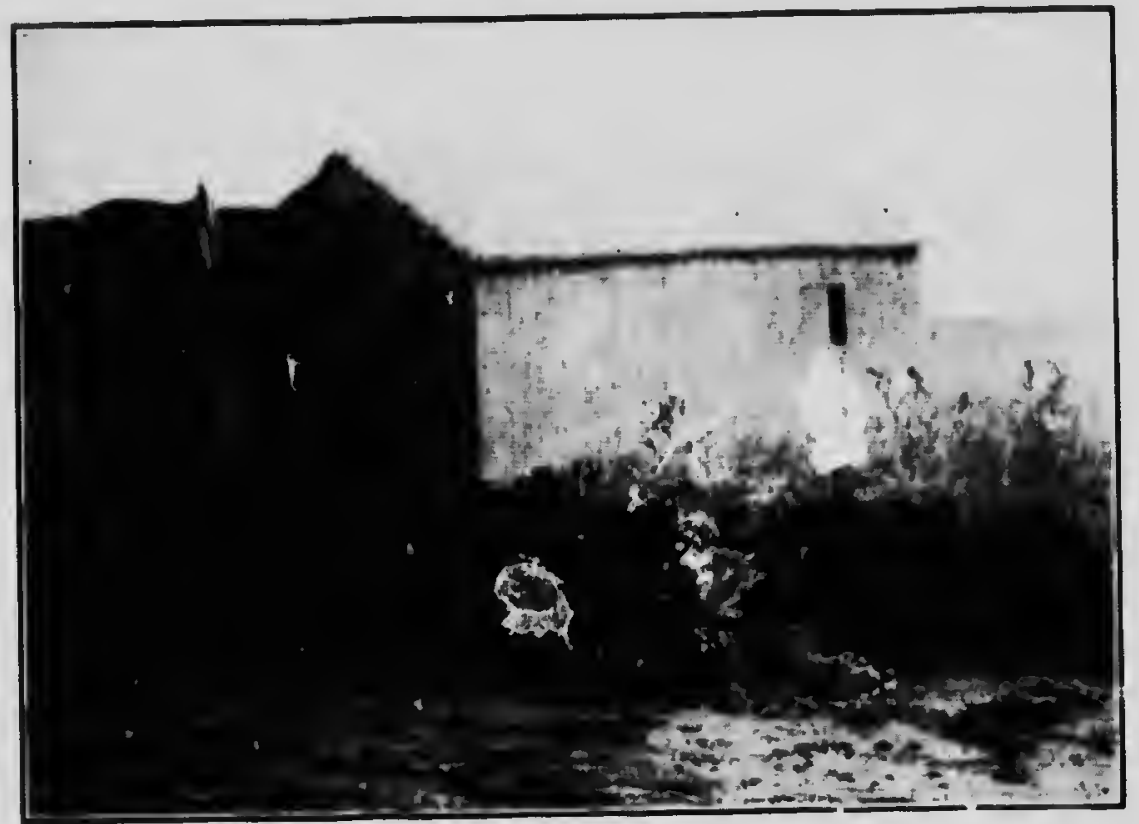

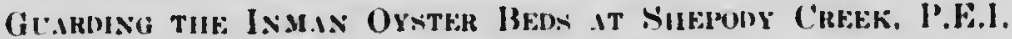
Owners have to protect their own hede from poachern. A guard armed with an Enfield rifle orcupies this house at night. 


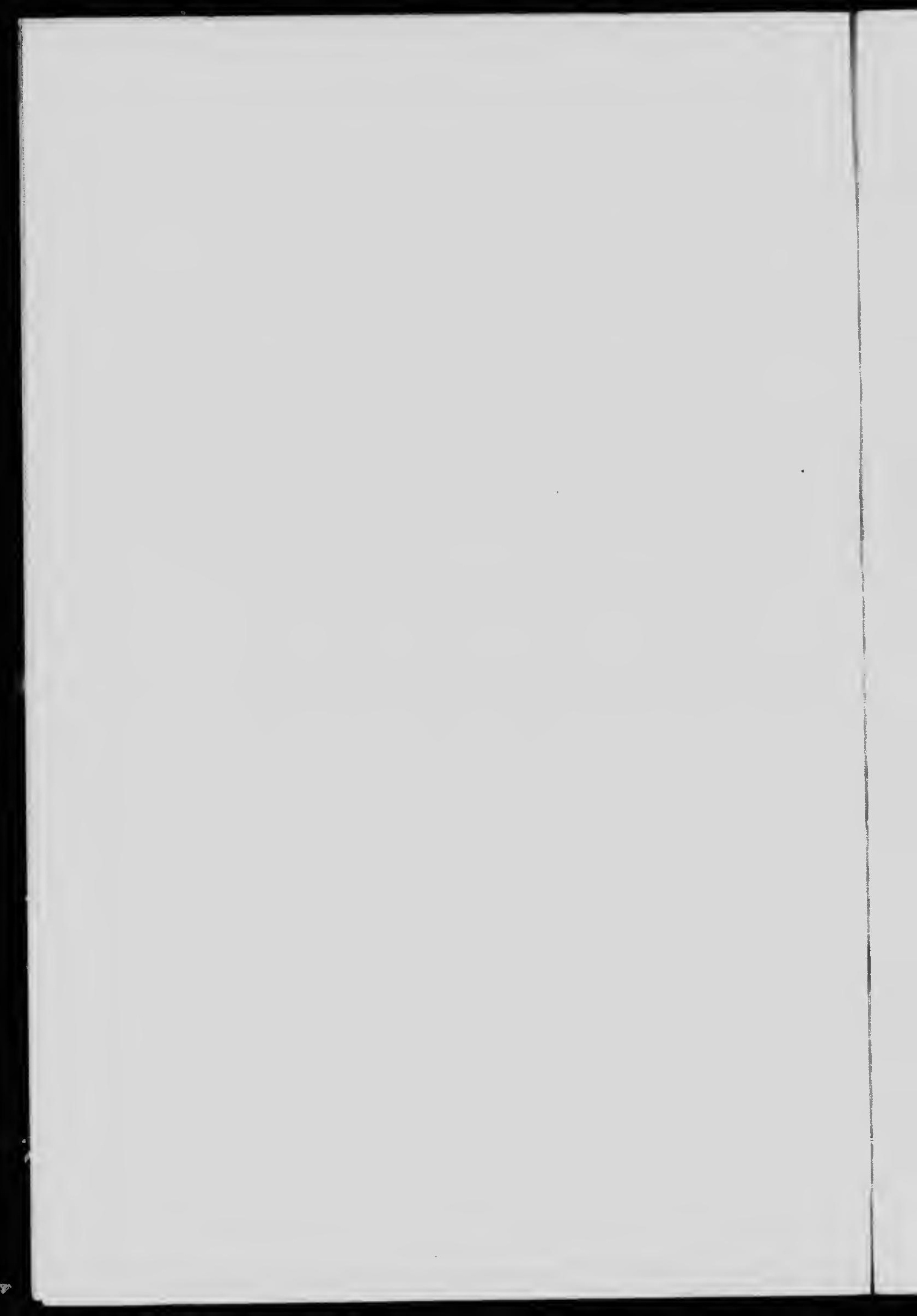


produced now come from the north, or Gulf shore of the Island, the principal indentation of which is Richmond bay. Other than this lastnamed bay, the chief oyster-producing areas ire found at East river, East Bideford, Mill river and Hill river. At East Bideford good quality cup oysters are produced. A supcrior grade of oyster is grown liere on the private areas of Sharp Bros., the oldest cultivated beds in the Province. The natural beds produce considerable quantities but the uneultivated oyster is always smaller and of poorer sliape than that grown on eultivated bottoms. At Hill river and Mill river a long thin oyster is found, much inferior as regards both size and flavour to those of East Bideford and Richmond bay. To the east of Richmond bay, in Last river, large quantities of oysters are fished from the natural beds. The East River oyster is well shaped but the fisliermen say it is saturated with salt water when caught and does not taste as well as the Curtain Island nyster. It is said to keep better than the Curtain Island variety, however, and inproves in flavour as it remains longer out of the water. At Enmore river, on Northumberland strait, a small round oyster of good quality is found, though in very small quantities. The bottoms here and in Percival bay are conceded locally to be good prospective oyster-farming areas. Limited quantities of oysters of very fair quality are also taken from Pereival bay, Orwell hay, Ternon river, and other portions of Hillsborough hay. No oysters are taken from the waters of hings county, although the existence of decp beds of old oyster shells slows how plentiful they once were there, and suggests the possibility of successful eultural operations.

\section{Present Oyster-Cultuke Oper.ations in Prince Edward Istand}

Despite the unsatisfactory titles obtainable for oyster areas prior to 1912, there are a few oyster farmers who have managed to cultirate beds. The oldest and largest private beds on the Island are those in the Narrows at Fast Bideford belonging to Sharp Bros. The title to these ean not be disputed because the grant was made prior to Confederation and the British North America Aet provides that proprictary rights rested in individuals prior to the passing of that act are not affected by its terms.

The area now held by Sharp Bros. was formerly the Sharp Bros.' property of the Pope fanily and passed eventually into Beds the hands of John Richards, from whom Sharp Bros. purehased it. It is situated at Squirrel ereek and comprises an area of from 10 to 50 aeres, the cxaet extent not heing easily arrived at on 
account of the indefiniteness of the boundary deseriptions. The area comprises about 5 acres of an old natural bed and, including this, there is now about 8 acres under cultivation. With the exception of the 5 acres of old natural bed, the area has a soft blue mud bottom, thickly overgrown with eel grass. On 3 acres of this mud bottom a solid bottom has been made by sinking rafts made of $5 / 8$-in. lumber covered with gravel and old shells. Inferior oysters picked from the public beds are planted on these artificial bottoms. The area of the producing bottoms is being extended in this way at the rate of an acre a year. It has been found that the lumber, when sunk in this blue mud, is protected from the attacks of marine borers and will last indefinitely. The cost of making bottoms of this description and stocking them with seed oysters is about $\$ 1,000$ an acre.

Sharp Bros. consider 500 to 700 bushels of sced oysters of such a size as to be ready for market in a year, sufficient to stock an acre. In eighteen months the oyster increases from one-third to onc-half in size. They depend mainly, however, on the set of spat to re-stock the beds. This has proved remarkably abundant and the whole area held is covered with a multitude of small oysters that attached themselves to the shells and old oystcrs this year. Not only this, but the public beds in the vicinity are heavily stocked with spat from these private beds. The fishermen say that they have never scen such a heavy catch before. At une lift of the tongs covering an area of $9 \mathrm{sq}$. ft. of hottom we lifted 75 oysters of all sizes-that is over 8 to the square foot. This lift was taken from the old bed, not from ones recently planted on the board bottoms. As an instance of the efficacy of the set of spat to stock the areas, Sharp Bros. informed me that it was a very common occurrence to get 100 oysters at a tongful from bottoms where no seed oysters had been planted.

Last year, 100 barrels of American seed oysters were importeit. These came from Long island and Oyster bay, but were purchased through New York commission men. The cost was $\$ 5.35$ a barrel, delivered.

The harvest from the Sharp heds during the past three years has been as follows :

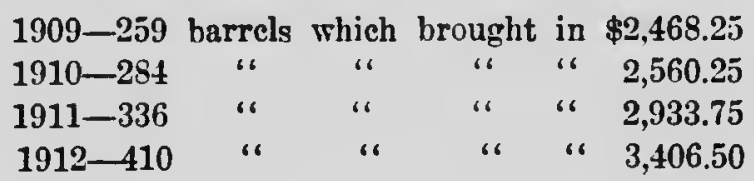


The number of barrels in each of the years above alluded to from 1909 to 1911 includes about 80 barrels taken from the public beds. In 1912 , about 150 barrels were taken from the public beds.

The Inman beds, situated on Shemody creek on RichInmen Beds mond bay, differ from the Sharp beds in having quite shallow water over them, the depth in some places at low water being little more than a foot. They cover an area of approximately $51 / 2$ acres and are held under lease from the Dominion Govern. ment by T. H. E. Inman and James Morrison of Summerside. The authority of the Dominion Government to grant such leases being ques. tioned, the lessees naturally have been troubled a good deal by poachers. Incleed, they had $\$ 80$ worth of oysters stolen in a single night a year ago last autumn. Since then a man armed with an Enfield rifle has been stationed in a little house on the shore to guard the property. (See illustration facing page 78.)

The nucleus of the bed is an old natural bed, but planting is being done on contiguous barren bottoms as well as on this natural bed. Small and medium sized oysters, imported from the United States at a cost of about $\$ 4.50$ a barrel, delivered, are used for plan ing purposes. These thrive remarkably well and Mr. Inman is of the opinion that they reproduce here. It must be remembered, however, that the shallow water on these beds is of a mueh higher temperature than deeper water would be. The shallowness of the water also makes it necessary to harvest in the autumn oysters planted in the spring, in order to avoid the destructive action of the icc. The seed oysters grow fast, howerer, (increasing about one-third in bulk in six months) and a handsome profit is made by buying in the spring at $\$ 4.50$ a barrel and selling the inereased yield in the fall at around $\$ 8$ a barrel.

Mr. Major McKinnon has the remnant of a planted Tracadie oyster bed on Tracadie bay, which has a soft mud bottom. Bay Mr. McKinnon stated that four years ago he had prepared a bed here and planted 140 barrels of oysters on it. During the winter lie was absent from home and, on his return, found two mud-digging maehines busily engaged in digging out his oyster bed. They destroyed it all exeept a tringe around the outside, and even this was hadly silted up. Under the law cxisting then, he could secure no redress. The few remaining oysters, in spite of the diffieulties to be overeome, had propagated and developed rapidly.

The method adopted by Mr. MeKinnon in preparing a bed on a mud bottom differs eonsiderably from that of Sharp Bros. First, he sinks a raft of poles on which brush to a depth of about 10 inehes is 
laid. Over this be plaees about 5 inehes of broken stone upon which cuitch to a depth of 3 inches is spread. Sueh a bed is placed ennsiderably above the level of the surrounding bottom and he elaims the rise and fall of the tide eauses a greater eurrent of water to flow over it, thus affording the oysters additional food. He estimated that $200 \mathrm{bar}$ rels of seed oysters planted in the spring in Tracadie bay would grow to 300 barrels by fall. In his opinion a first-elass produeing oyster bed one aere in area was worth $\$ 5,000$.

Mr. H. C. Mills, an oyster dealer in Summerside, said Locke Shore that he had imported nearly 100 barrels of Ameriean oysters last fall and planted them in Malpeque bay off Loeke shore. They had done well in their new environment and the experiment was eneouraging in every sense. Outside of these fer instanees praetically no oyster farming has been done in Prinee Edward Island. The sueeess that these men have had, however, together with the new eonditions whereby a valid lease ean be granted, makes it very probable that a flourishing industry will be built up in the eourse of a few years.

\section{Important CONSIDERations in OYster CULture}

While the area of barren bottoms eapable of produeing

Choice of oysters is very large, the faet must not be lost sight of that loeations vary widely in their suitability for oyster-eulture work. One of the first requisites of a sueessful oyster bed is a firm, hard bottom. There is a great deal of soft mud bottom around the shores of Prince Edward Island and if oyster planting is to be done oll these, the first thing to be done is to eonstruet over the mud a firm hard bottom on which the eultch and the spawners may be laid. Sometimes this artifieial bottom is made of board rafts eovered with gravel and shells, sometimes of poles, brushwood and roek, the material usei repending on its availability and eheapness in the partieular loeality.

The importanee of seleeting a suitable bottom for plantMurray Barbour Bed ing eannot be over-estimated. In many plaees around Prinee Edward Island, especially on muddy bottoms, there is a heavy growth of eel grass which is inimieal to the development of oysters. The history of the bed planted at Murray harbour by Captain Kemp brings out this diffieulty well. The bed was prepared in 1899 and planted with 84 barrels of small oysters. I inspeeted the bed from a launeh and found that it liad been planted on a mud bottom and that 
there was an exceedingly heavy growth of eel grass over it. It liad becn given no attention sinee 1907 and I was told that many of the oysters had been stolen from it. We made about twenty-five lifts witl the tongs and took only one oyster. This was a cup oyster of good quality, about $41 / 2$ inehes long, which had been partially buried in the nud. Several other specimens werc brought up, which at first were thought to be alive, but on closer examination, it was found that there were no oysters between the shells. As the linges were intact, it is likely that the oysters had grown to this size before being eventually smothered by the mud and eel grass. The character of the bottom in Iurray harbour was examined in several places and, in every ease, it. was found to be black mud covered witl eel grass. The condition of this bed illustrates the diffieulty that the oyster farmer will have to meet if lie plants on a mud bottom that has not heen properly pre. yared and is not earefully looked after.

In determining the loention of a bed, eare should also Salinity and he taken to sec that the water at low tide is suffieiently deep to prevent the iee damaging the oysters in the winter and in the spring. Then, again, the salinity of the water eovering the beds is a matter of no small importanee. If too much fresh water mingles with the salt at that point the oysters will not do so well and their texture will be flably. If the temperature of the water is low. growth will be slower than in warmer water, although the quality of the meat will be better. The depth of water over the bed largely determines its temperature, the shallower water being warmer than the deeper. Where the water is cold the spatting oecurs later in the season, and when oysters from the warmer waters of the United States are planted in our cold waters, they are not likely to spawn until they become aeelimatized. The waters of various plaees also vary widely in their nutritive value. One of the greatest needs of the oyster farming industry in Canada to-day is seientific analysis of the water over prosprective oyster areas to determine whether it is surficiently nutritive to justify the expense of planting operations.

Mud Digging and Oyster Farming

The digging of oystes mud in the rinter hy the farmers bears an important relation to the work of oyster culture in several ways. In the first place, mud-digging operations carried on ton elose to an oyster hed are liable to smother the oysters with silt. The Dominion Fovernment, which, as before stated, has legislative jurisdietion over the fishery, has muled that mud digging must not be earried on nearer than 200 yards to a live oyster bed. and 
then, only on the written permit of a fishery inspector. Now that oyster farming is being engaged in, it is imperative that the fisheries officials exercise great care in granting permits for digging mud near cultivated oyster areas.

An additional use will be found for the dead oyster beds when a large area of bottoms comes under cultivation. The oyster farmer must have cultch to which the oyster larve may attach themselves in the spawning season and, in many localities, clean, large shells suitable for this purpose, may be obtained from old oyster beds. Sharp Bros., at East Bideford, now secure from these dead beds, a large proportion of the cultch used on their oyster bottoms. As the oyster trade of the Island is entirely a half-shell one, there is no possibility of procuring any of the sheils of the oysters now being fished.

Lastly, the mud digger comes into touch with the oyster farmer in that the areas from which he has dug out the oyster mud may possibly be again made to produce oysters. Mud digging is carried on everywhere along the coast, but the two bodies of water where it is most extensively pursued are Bedeque bay and St. Peter bay. From $\mathbf{5 0 0}$ to 600 cars of oyster mud are shipped from Bedeque bay eacl winter, while the mud-digging operations in St. Peter bay, where a depth of 39 feet in solid oyster beds has been reached, are on an even more exten. sive scale. The mud-digging machines have dredged out great furrows in the bottom of these bays and the surface left is so uneven that it could not possibly be utiinzed for planting oysters. Any young oyster placed in the furrows would soon be smothered by the silt drifting down from the higher portions of the bottom.

Extending the Oyster Ar:a

The Provincial Government, however, is considering a plan to obviate this difficulty. The proposal is to prohibit the public from digging mud on these bays and to install large steam dredges to draige out the old shells, leaving a level Lottom on which oysters mar be plantel. The farmers would be appeased hy being allowed to purchase at cost the shells thus lifter. This plan appears to be quite feasible, although only an actual test could definitely determine its success.

One thing at lesst is certain, and that is: The immense deposits of oyster shells show that the waters of these bays in years gone by were ominently suitable for the production of oysters. As a matter of fact, the flavour of the Redeque orsters still lingers in the memories of the older fishermen as being equalled only by those from Richmond bay. 


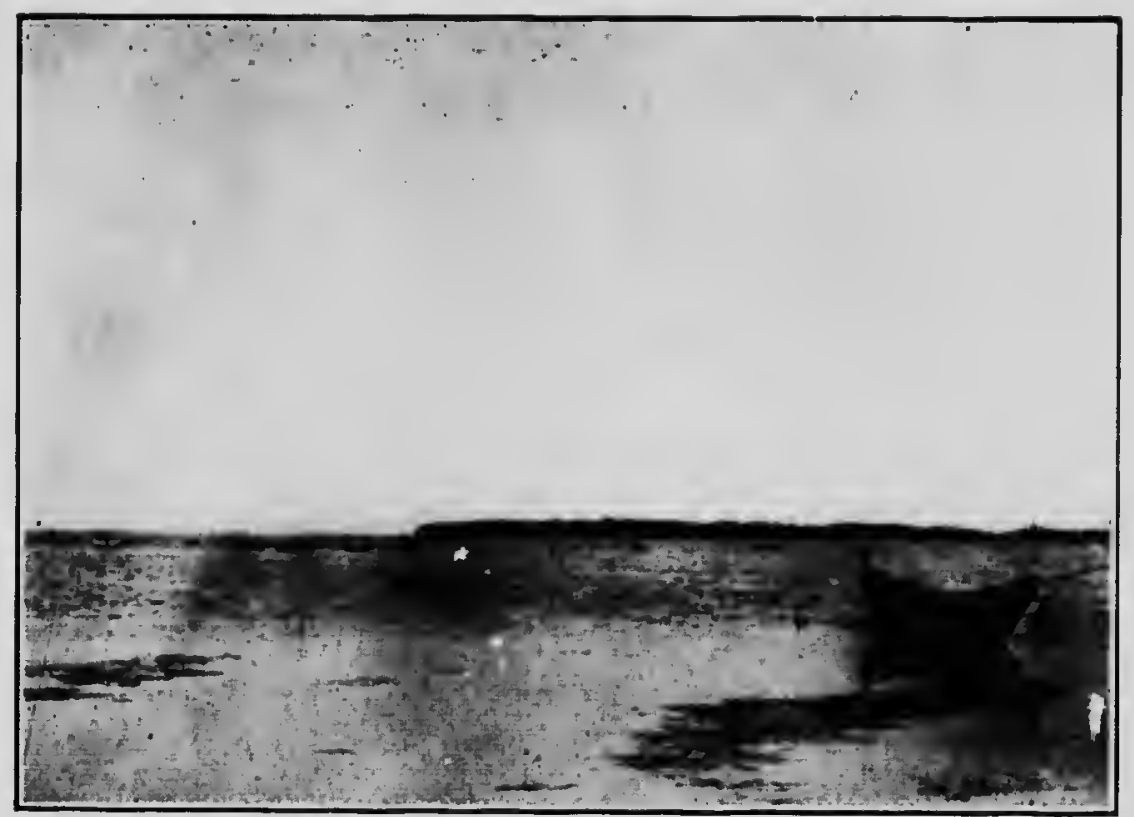

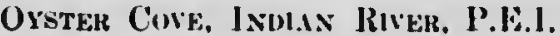

This inlet is an aru of Pichmond hay and is good putentiul oyster grouml. A small natural oyster led exiets off this shore.

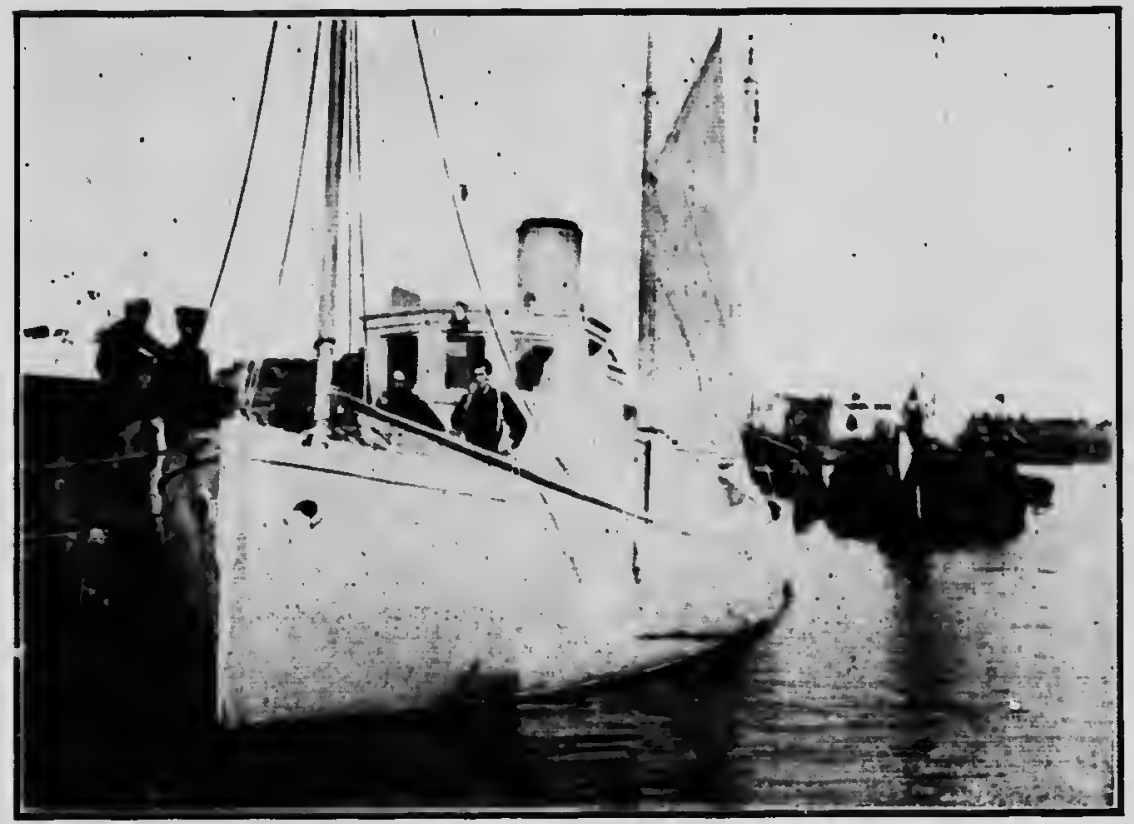

The Ostrea at ML.ILPEque, P.E.I.

This !ittle boat is overworked. She bas to keep the public oyster bedis in condition, look after the Dominion Government'o experimental oyster culture work and keep poachers off the oyeter bede of Canada's whole Atlantic reaboard. 

Determining Spat Settle

Another vital feaure in oyster culture is judging cor. rectly when the settling of the oyster spat takes place. The spawning season oceurs during the latter part of July und the larve settle as spat about the middle of August. If the culteh, to which it is intended these larve will attach themselves, is put down too long before the fixation of the larve occurs, it becomes slimy and the larvie eannot attach themselves to it. The aim of the oyster farmer is, therefore, to put down his eultch just before the fixation of the larve takes place. Professor Stafford of McGill University, in his study of the development of the oyster has perfected a method, by means of microseopic examination, whereby the time of fixation may le definitely determined. This, however, cannot be applied by the ordinary oyster farmer unless he has received some instruction in it. Until the appli. cation of this method can be made general, the time of putting out the eultch must be decided, as heretofore, hy rule of thumb. As soon as there are a considerable number of areas under cultivation in Prince Elward Island, it is very desirable that either the Dominion or the Provincial Government should instruct the oyster farmers how to apply l'rofessor Stafford's method.

\section{Fisheries Protective Service}

It is imperative that the Dominion fisheries protective service be inproved so as to afford adequate protection to cultivated oyster beds. In its present condition it is almost worthless. Sharp Bros. are compelled to keep a patrol bont on their oyster beds to ward off poaeherst and the Inman beds at Shemody ereek are protected by an armed sentinel on the shore. Now that the people of the Island are entering upon oxister farming on an extensive seale, it is absolutely necessary that the Dominion Government enforee the law.

The fisheries protective service, as at present organized,

System Defective is inefficient and must remain so as long as the present method of appointment prevails. Under the present system, the fishery guardians are local men-farmers or fishermenwho receive their appointment hecause of their political affiliations and are paid a small sum yearly for seeing that the fisheries regulations are enforced in their distriets. The appointee knows he was not appointed because of his peeuliar fitness for discharging the duties of his position,

* Prof. Stafford gires a popular exposition of this method in his article on "The Conservation of the Oygter," in . Ser-Fisheries of Eatern Canadu, publisher by the
Commigsinn of Conservation in 1912.

+ See illoetration facing page 78 . 
Lut because he belongs to a particular politieal party. The inevitalje result of this system is to cause him to regard his position as a sinecure and to make his attention to duty a most perfunetory one at beat. Noreover, the sulary given him tends to strengthen this imprension; it is so smull that he eould by no means devote much attention to his work. liesides, being a locul mun, he uust not he ton harl on his neighbours who break the luws now and again. If le were too striet, he and his family would he socially ostrucized. 'J'he result is a protective serviee that is lookel uyon as a jolve,$\cdots$ the whole conmmunity. In every little fishing hamlet there are sturic of how the luws are broken and of how the guardinns wink at law-breaking, kerping studiously out of the way when they know it is going on. Not only ean sueb an inefleient organization do but little to protect the fisheries, but it tends to debaueh the morals of the whole country whore it exists. No one who has not mingled among these people can imagine how it demoralizes the finer sensihilities of a law-ahidiug eitizenship and engenders a disrespeet for all law:

Suggestions

It is not so much the officials as the systein that is at for Improvefault. I nm of the opinion that the best results would be ment

achieved by appointing offieials at salaries which would permit them to give their whole time to their duties. If the guardians were paid adequate salaries and eompelled to give their whole attention to the work, fewer officials would be required to do the same amount of work. All the appointments should be marle on the ground of capability, not polities. Under no enn-ideration should guardinns for a district be appointed who are resiac.its of that distriet. If an officinl is to discharge his duties properly in any district, he must cone to it as a stringer. Furthermore, the ofieials should be moved to new distriets eve three or four years, and the inspectors placed over them should have ahsolute power to suspend and to dismiss them for inefficiency or neglect of duty. In no other way ean discipline be huilt up. It must he remembered that the people in these fishing distriets have been used to seeing the law scoffed at and trodden under foot for years and that the new organization will have to work against a strong publie feeling of suspicion. Talk ahout reorganization of the fisheries protective serv :e to these people and they will shake their heads in a knowing way and say, "Yes we have seen reorgarizations before and they all amounter to the same thing." To overcome this feeling on the part of the people the service must be placed under a rigid system of inspection anit strong-handed discipline. 


\section{Reviston of Pufaldat Reaulitions}

Close

Sesmon and

Marketing

Onew the protective service las leen reorganized the next essential is a thorough revision of the existing regulations respecting oyster fishing. The present regulations were intended to apply to free-fishing conditions and not to conditions where oyster culture prevails. The regulation fixing a close senwon, although quite proper when it was formulated, hrs, with the advent of oyster tarming, becomo most unjust and unfi... The effect of it is to prevent the oyster farmer from marketing his crop except in the open oysterfishing season which cxtcnds from October 1 to March 31. The result is that, on account of winter conditions, oysters can be fished and marketed practically only luring two months of the yenr. As a consepuenee, large quantitics are thrown on the market during these two months and prices are demoralized. When a man plants and cares for an oyster bed there is no good reason why he should not be allowed to sell his oysters at any time they ean he profitably marketed. Sclf-interest will force hir. to see that he does not worn injury to his bed. It can readily be seen how the progress of oyster farming will be retardzd unless prn. vision is made whereby oyster culturists may market their products nt any time they choose to do so.

The fixing of a standard-sized oyster barrel and the Packing and establishment of a system of government inspection anil hranding of the packages are two other matters which require the immediate attention of the Department. I lave interviewed the largest oyster dealers in Montreal on this subject and they are unanimous in their opinion that the Prince Edward Island oysters, althongh naturally superior in quality, cannot hold their own against the United States oyster unless they are properly graded and put up in packages of fixed size. Oyster consumers, they dcelarc, demand the highest elass article they can procure, regardless of cost. This, however, is a fact that the oyster fisherman cannot fully appreciate, and consequently, he is ruining his own prospects by shipping small and inferior oysters in packages of all sizes. When a retailer buys a barrel of oysters he must know approximately how many oysters there are in it, else he cannot determine the proper price at which to sell them. If the barrel is not of standard size and the oysters are not graded, he sells them at either too high or too low a price. Thus, either the customer or the dealer is chented, and either contingency is disastrous to the Prince Fdward Island oyster. 
It is to be expected that, witl the inauguration of oyster

Inspection and eulture, an attempt will be mado to market large quantities

Branding of trnnsplanted United States oyater as senuine Mni. peques. Although mel oysters, after being in Prinee Fiward Inlani watem a certain length of time, do nbsorb the flavour of the native pru. duet, yet the knowledge that they are being wold esnnot help lut interfere with the market for the well-known Jlalpeques. It is necessary that these linited States seed oyaters be imported for a few years till the berls can be adequately stocked, but, when being marketed, they should hes carefully distinguished from the l'rince Jidward Island oyster. This distinetion cannot be mnde unless a Governuent nystem of inspection and brunding is estahlishei.

In sumuarizing, it may he said that the prospects for St:mmary the estallishment of a profitable oyster-farming industry in l'rince Eilward Island are encouraging. Now thut the? oyster finruer can procure gool titles to bottoms, the responsilility rests nu the Domiuion Goverument and the l'rovineial gorernuments to see llat the conditions under which le works be made as favomrable ar possible. What is most urgently needed is a elingge in the present oyster. fishing regulations which were not intended to apply to oyster-(en!luri cuntitions. This will, no douht, le speedily eftected; no gond renson ean be alraneed why it slould not be. The neel for the reform of th: fisheries pretective service is particulirly urgent. As eoustitutel at present, it is ineffeetive ir protecting the fishers and is dehasing the morai tone of the fisling eommunities as well. That a reorganization is uranty required is almitted ly all ; the clanger lies in continued lelay. As little is known scientifieally about the propagntion of oysters in Can. adian waters, it would he a abent loon to the oyster farmers if th" governmenty roucerned would hare seientific resenceles macle ly a ma! of scientifie attainments, who could also appreciate the practienl am! erononic aspects of the industry. No argument ean lie alvaneel why :! standari-sized harrel -hould not be adopted by law and a system o! government banding estahlished. The markets require it and an "xtencled inrestigntion is not necessary to determine tlu details. Just at. present people in Prinee Fdward Islanl are very enthusiastic orel the husiness of oyster farming. It is, howerer, an industry in which sucess can not be won without the possession of neenrate knowledge and the adoption of sonnd husiness prineiples, and it therefore helinoves the government authorities to do all in their porrer to prevent this in. ${ }^{+}$ia! enthrusiasm of the oyster farmer from heing dulled. 


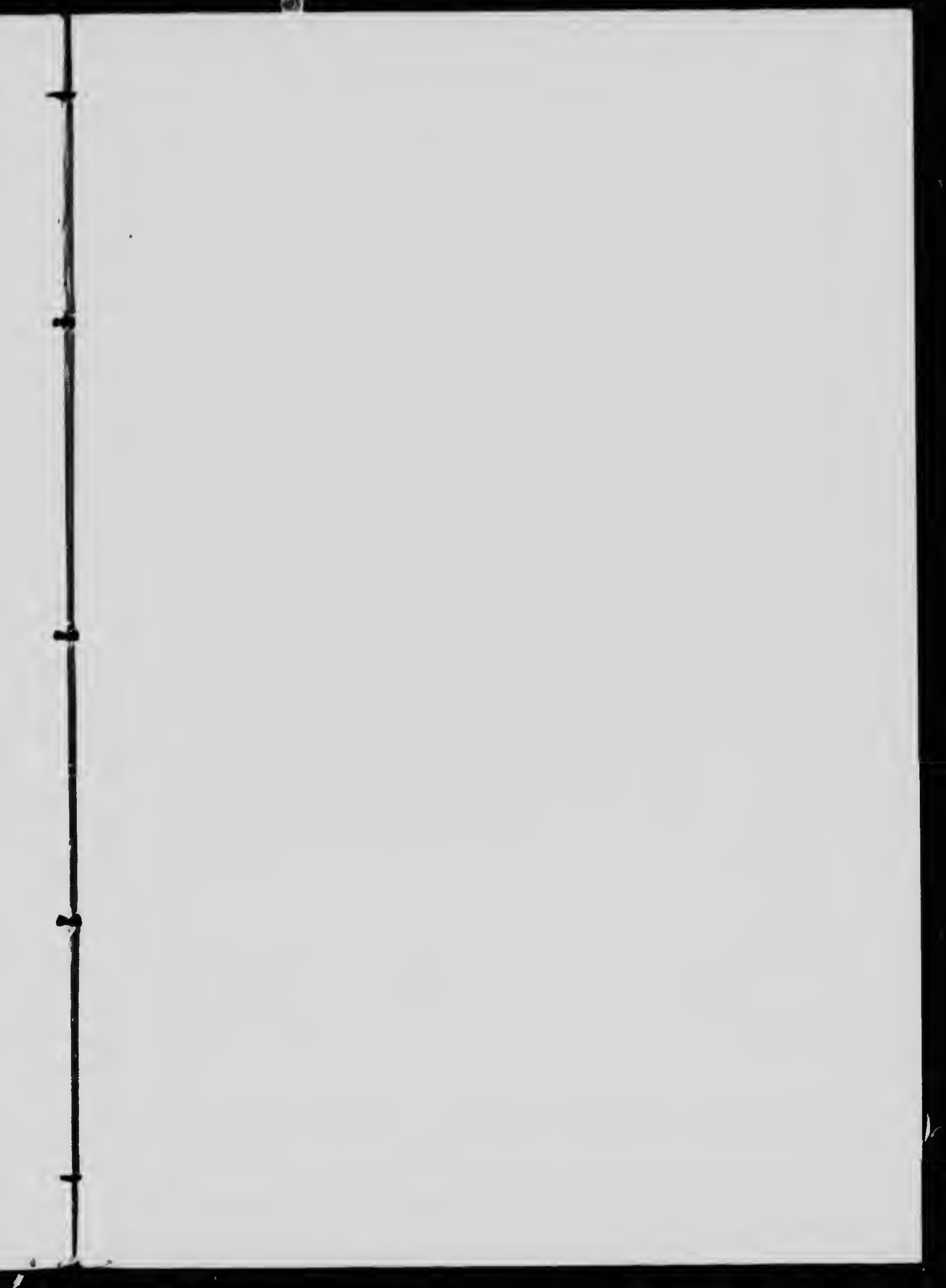




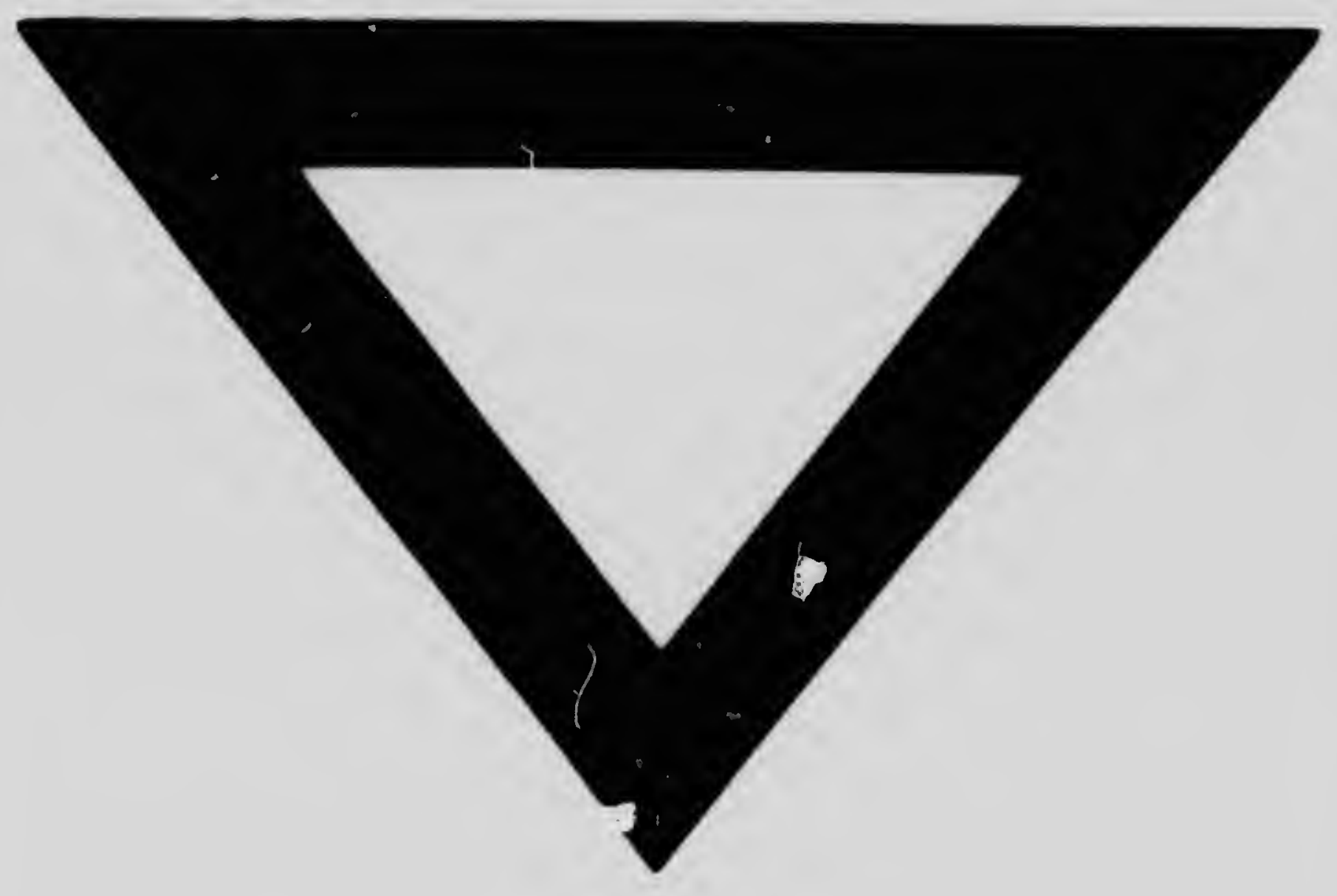

